\title{
Retraction Note: Microarray analysis for differentially expressed genes of patients undergoing total knee arthroplasty with ischemia preconditioning
}

\author{
Jianguang Wang ${ }^{1,2}$, Zhengdong Cai ${ }^{3,4,5^{*}}$ and Junjian Liu ${ }^{2,5^{*}}$
}

\section{Retraction}

The Publisher and Editor regretfully retract this article [1] because the peer-review process was inappropriately influenced and compromised. As a result, the scientific integrity of the article cannot be guaranteed. A systematic and detailed investigation suggests that a third party was involved in supplying fabricated details of potential peer reviewers for a large number of manuscripts submitted to different journals. In accordance with recommendations from COPE we have retracted all affected published articles, including this one. It was not possible to determine beyond doubt that the authors of this particular article were aware of any third party attempts to manipulate peer review of their manuscript.

\section{Author details \\ 1The Affiliated Shanghai No.10 People's Hospital, Nanjing Medical University, Shanghai 200072, China. ${ }^{2}$ Department of Orthopedics, Shanghai Tenth People's Hospital, Tongji University School of Medicine, Shanghai 200072, \\ China. ${ }^{3}$ The Affiliated Shanghai No.1 People's Hospital, Nanjing Medical University, Shanghai 200080, China. ${ }^{4}$ Department of Orthopedics, Shanghai First People's Hospital, Shanghai Jiao Tong University, Shanghai 200080, China. ${ }^{5}$ Department of Orthopedics, Shanghai First People's Hospital, No.100 Haining Road, Hongkou District, Shanghai 200080, China.}

Received: 4 March 2015 Accepted: 4 March 2015

Published online: 26 March 2015

\section{Reference}

1. Wang J, Cai Z, Liu J. Microarray analysis for differentially expressed genes of patients undergoing total knee arthroplasty with ischemia preconditioning. J Orthop Surg Res. 2014;9:133.

\footnotetext{
*Correspondence: amarantine@163.com; junjianliu0917@163.com ${ }^{3}$ The Affiliated Shanghai No.1 People's Hospital, Nanjing Medical University, Shanghai 200080, China

2Department of Orthopedics, Shanghai Tenth People's Hospital, Tongji University School of Medicine, Shanghai 200072, China

Full list of author information is available at the end of the article
}

\section{Submit your next manuscript to BioMed Central and take full advantage of:}

- Convenient online submission

- Thorough peer review

- No space constraints or color figure charges

- Immediate publication on acceptance

- Inclusion in PubMed, CAS, Scopus and Google Scholar

- Research which is freely available for redistribution

Submit your manuscript at 